\title{
Isolation and Characterization of Bacteria with Biochemical and Pharmacological Importance from Soil Samples of Dhaka City
}

\author{
Kohinur Begum ${ }^{1}$, Sultana J uhara Mannan ${ }^{1}$, Refaya Rezwan ${ }^{1}$, Md. Mahinur \\ Rahman $^{1}$, Md. Shajidur Rahman ${ }^{1}$ and Alam Nur-E-Kamal ${ }^{2}$ \\ ${ }^{1}$ Department of Pharmacy, ASA University Bangladesh, ASA Tower, Shyamoli, Dhaka-1207, Bangladesh. \\ ${ }^{2}$ Department of Biology, Medgar Evers College of the City University of New York, 1638 Bedford Avenue, \\ Brooklyn, New York11225, USA.
}

(Received: May 20, 2017; Accepted: June 19, 2017; Published (web): June 21, 2017)

\begin{abstract}
We studied soil samples from Dhaka municipality area to isolate and characterize bacteria having potential biochemical and pharmacological importance. Total twenty five soil samples were collected from fish, vegetables and fruits dump area from Dhaka City. Bacterial population was sub-cultured in trypticase soya agar (TSA) plate. Nineteen colonies were isolated, cultured and characterized by gram staining and biochemical tests. Six isolates were found to be gram negative while thirteen were gram positive. All isolates were positive in oxidase, catalase, citrate, and protease tests. Eight isolates showed coagulase negative and nine were coagulase positive. It was found that all bacterial isolates were sensitive to tetracycline, chloramphenicol, gentamycin, ciprofloxacin, azithromycin and ceftriaxone. About $95 \%$ of the bacterial isolates were resistant to penicillin-G and ampicillin. About $89 \%$, 26\%, $21 \%$ and $11 \%$ of the bacterial isolates were resistant to amoxicillin, co-trimoxazole, nalidixic acid and erythromycin, respectively. It was found that bacterial isolates produce chemical(s) inhibitory to other bacterial strains including both gram positive and gram negative bacteria. Further studies are needed to characterize the potential antibacterial factor(s) and other bioactive compound (s) present in these bacterial isolates from soil samples.
\end{abstract}

Key words: Soil bacteria, isolation, protease, antibacterial activity

\section{INTRODUCTION}

Microbial population in soil counts for a huge mass of organic matter on earth. Importance of microorganism in maintaining human habitat on earth is now beyond a question of discussion. These microorganisms are of very diverse that includes bacteria, archaea, yeast, fungi, algae, and protozoa. ${ }^{1}$ Microorganisms can live in environment along with human and in extreme conditions such hot springs, miles deep in the ocean, inside rocks and in extreme cold temperature. ${ }^{2}$ Although the number of microorganisms varies in different places, it has been indicated that mass of carbon from these microorganisms could be trillions of tons..$^{3-5}$

Correspondence to: Kohinur Begum

E-mail:prof.kohinur@asaub.edu.bd/kohinur025@yahoo.com

Dhaka Univ. J. Pharm. Sci. 16(1): 129-136, 2017 (June)
Bacterial population in soil performs key roles in nutrient cycles including Nitrosomonas and Nitrobacter (nitrification), Thiobacillus (sulfur and iron oxidation), Rhizobium and Frankia (N2 fixation), Bacillus and Clostridium (carbon cycling) and Caulobacter and Pseudomonas (manganese oxidation). ${ }^{6}$ In addition, a large number of bacteria have been discovered to produce various types of chemicals that are being exploited in biotechnology industries. ${ }^{7-9}$ Most of the bacteria in soil remain unidentified. Both academic and industrial scientists realized that soil bacteria are a potential source to find unique biologically active metabolites and novel commercially important products. Bacteria have been found as a source of producing many valuable chemicals including ethanol, acetone, enzymes, perfumes, antibiotics. In the last few decades thousands of antibiotics have been discovered. ${ }^{10-12}$ 
Antibiotic resistance is a great challenge to modern medicine and demands discovery of novel antibiotics. ${ }^{13-14}$ Microorganisms were found of producing secondary metabolites with a diverse chemical structure and antimicrobial activities. ${ }^{15-16}$ These findings raise a high possibility to identify bacterial strains from soil samples that might produce reagents with biochemical and pharmacological importance.

The numbers and species of microbes in soil is depended on environmental conditions like nutrient availability, soil texture, presence of moisture in soil and type of vegetation cover, and other environmental conditions. ${ }^{17}$ Among many other commercially important enzymes, proteases are another large group of industrial enzymes with significant industrial use being isolated from microorganisms. ${ }^{18}$ In order to meet the demand of enzymes and antibiotics for industrial application, it is critical to isolate novel bacteria that could be used to produce the chemicals of such application. Nutrient content in soil varies from area to area. A high content of nutrient is likely to be soil where organic waste is dumped. Accordingly, soil samples of organic dump site will have varieties of nutrient in higher amount. Bacteria will favorably grow in such soil samples and historically preferable sites for sample collection for isolation of novel bacteria. ${ }^{19} \mathrm{We}$ have taken a project to study bacterial population in soil samples from fish and vegetable dump areas in Dhaka city. We have studied their biochemical and morphological properties. ${ }^{20}$ In this study we have found that some of our bacterial isolates produce factors of biochemical and pharmacological importance.

\section{MATERIALS AND METHODS}

Chemicals and reagents. Trypticase soy broth (Hi-Media, India), Trypticase soy agar (Hi-Media, India), Muller-Hinton agar (Hi-Media, India), Luria Bertani broth (Hi-Media, India), Kligler's iron agar (Hi-Media, India), hydrogen peroxide, N, N, N1 N1- tetra methyl-P-phenyldiamine-dihydrochloride (sigma), simmons citrate agar (Hi-Media, India), commercial antibiotic disc (Hi-Media, India).

Sample collection. Soil samples were collected from fish, vegetables and fruits dump area during March-June, 2016 from Dhaka City.

Bacterial culture. Five gram of each soil sample was suspended in $25 \mathrm{ml}$ of TSB. Bacterial suspension was diluted $\left(10^{-4}\right)$ with saline water and $100 \mu \mathrm{l}$ of bacterial suspension was spreaded on TSA plate and incubated for 24 hours. Bacterial colonies were isolated and grown in TSB. Bacteria were characterized by biochemical analysis as described below.

Gram staining. Gram staining was performed for all isolated colonies according to the standard procedure. A smear of bacterial cells was prepared on a clean glass slide by a gentle heat fixation. The heat fixed smear was flooded with crystal violet solution for one minute. Smear was washed with water followed by adding mordant Gram's iodine. The smear was decolorized with 95\% ethyl alcohol and rinsed with water. Finally safranin was used as counter stains for $60-80 \mathrm{sec}$ and washed with water. Cells were then examined under microscope. $S$. aureus ATCC 25923 and E. coli ATCC 25922 were used as gram positive and gram negative control, respectively.

Catalase test. A drop of 3\% hydrogen peroxide was added to a bacterial colony on a sterile glass slide and mixed well. Production of air bubble was observed for a minute. Production of air bubble indicated catalase positive and no bubble indicated catalase negative. S. aureus ATCC 25923 and E. coli ATCC 25922 were used as positive and negative control, respectively.

Coagulase test. All isolates were tested for coagulase test using human plasma serum. Two drops of saline water was taken onto the slide and mixed with the bacterial sample. A drop of serum was added on the saline drop and mixed well. The slide was rocked gently for about 10 seconds. Positive test was indicated by clumping of bacterial cells in the plasma within 10 seconds. Failing to form bacterial cells clump indicates a negative result for coagulase test. 
S. aureus ATCC 25923 and E. coli ATCC 25922 were used as positive and negative control, respectively.

Oxidase test. Oxidase test was performed with $1 \%$ solution of $\mathrm{N}, \mathrm{N}, \quad \mathrm{N}^{1} \mathrm{~N}^{1}$-Tetra methyl-pphenyldiamine-dihydrochloride which was socked in a piece of filter paper. A portion of the colony of the test organism was picked up with a sterile tooth pick and touched on to the paper with impregnated reagent. A dark purple color development within 510 second was considered positive and no change of color was interpreted as a negative result for oxidase. Pseudomonas aeruginosa and E. coli ATCC 25922 were used as positive and negative control, respectively.

Kilger's iron agar (KIA) test. All bacterial isolates were tested for KIA test to study the mode of dextrose utilization in oxidative/fermentative test. Slant of KIA media were inoculated by stabbing the butt and streaking the slant and incubated at $37^{\circ} \mathrm{C}$ for 24 hours. Results were recorded for changing in color of the butt or slant, $\mathrm{H}_{2} \mathrm{~S}$ or other gas production. Production of hydrogen sulphide causes change of color of the medium to black and the gas production give rise to bubble formation. S. aureus ATCC 25923 was used as positive control.

Simmons citrate test. Isolates were tested to determine the utilization of citrate as the sole source of carbon for metabolism. Tubes of citrate media were inoculated by streaking the slant with bacteria and incubated at $37^{\circ} \mathrm{C}$ for 24 hours. Results were recorded for change in color of citrate media. $S$. aureus ATCC 25923 and E. coli ATCC 25922 were used as positive and negative control, respectively.

Protease test. The protease activity was performed using LB agar plate containing 1\% skim milk. A small portion of bacterial colony was inoculated as spot agar plate and incubated for 24 hours at $37^{\circ} \mathrm{C}$. Protease producing ability of each bacterial inoculum was assessed by hydrolyzing milk protein surrounding the colony and producing a transparent clear zone. The clear zones around the colonies indicated protease activity. Pseudomonas spp. and Klebsiella spp. were used as positive and negative control, respectively.

Bactericidal activity of soil isolates bacteria. Bacterial strains isolated from soil samples were studied to determine their ability to kill pathogenic bacteria including E. coli, $V$. cholerae, $S$ aureus, and B. subtilis. Test bacteria were spreaded on MullerHinton (MH) agar plates. Each of the soil bacterial isolate was then inoculated as small spot with appropriate marking. The plates were then incubated at $37^{\circ} \mathrm{C}$ for 24 hours. Bacteria which can kill or produce chemicals that inhibit bacterial growth exhibited clear transparent zones around the inoculated spot of inoculation. After 24 hours of incubation, zone diameter was determined and recorded.

Antibiotic sensitivity test. Antibacterial susceptibility test was performed by the Kirby-Bauer disc diffusion method on Muller-Hinton agar plates. ${ }^{21}$ Each bacterial isolate was spreaded on $\mathrm{MH}$ agar plate. Then antibiotic discs were inserted on surface of the $\mathrm{MH}$ agar plate. Plates were incubated at $37^{\circ} \mathrm{C}$ for 24 hours. Sensitivity of individual antibiotic was determined by measuring zone diameter. Twelve commercially available antibacterial discs (Hi-media, India) were used including tetracycline (TE, $30 \mu \mathrm{g}$ ), chloramphenicol (C, $30 \mu \mathrm{g}$ ), gentamycin (GEN, 10 $\mu \mathrm{g}$ ), erythromycin (E, $15 \mu \mathrm{g})$, ciprofloxacin (CIP, $5 \mu \mathrm{g}$ ), nalidixic acid (NA, 30 $\mu$ g), ampicillin (AMP, $25 \mu \mathrm{g}$ ), azithromycin (AZM, $15 \mu \mathrm{g}$ ), ceftriaxone (CTR, $30 \mu \mathrm{g})$, penicillin-G (P, $10 \mu \mathrm{g})$, amoxicillin (AMX, $30 \mu \mathrm{g}$ ), co-trimoxazole (COT, $25 \mu \mathrm{g}$ ). Diameter of the zone of inhibition around each antibiotic disc was recorded in millimeters to determine the sensitivity or resistant categories according to the standard chart of Hi-media.

\section{RESULTS AND DISCUSSION}

Some of the microbes produce enzymes and chemicals that are highly useful for human. Food waste dumps decompose to organic material providing abundant nutrient supply for microbial growth. Growth of different microorganisms in rotten food on soil depends on the type of waste food dump. 
Due to warm temperature in Bangladesh it is likely that food dump area is an excellent environment for bacterial growth. In this report we have studied bacterial population in different food waste dumping area of Dhaka city. Soil samples were collected from fish and vegetable waste dumping area of Dhaka city. Bacterial colonies were identified based on their color and morphology (Table 1, Figure 1). A total of 19 single colonies were picked up and cultured in TSB for further analysis. In order to characterize bacterial isolates, gram staining and biochemical tests were performed. It was found that $79 \%$ isolates were gram positive while $26 \%$ were gram negative (Table 1). In microscopic analysis, some bacteria were of round shape and some were rod shape (data not shown). The results obtained in this study is consistent with the previous studies in other countries. ${ }^{22,23}$ These soil microorganisms may be an important source of producing chemicals having biochemical and pharmacological importance. Although many useful chemicals have been discovered as microbial metabolites, there might be many more products yet to be discovered from soil microorganisms. ${ }^{24}$ In our preliminary study, we screened bacterial isolates from waste dump sites for the presence of enzymes such as protease, oxidase, catalase, coagulase (Table 2). All soil bacterial isolates studied for their synthesis of proteins using casein (milk protein) as substrates. It was found that all bacterial isolates produce protease (Table 2 and Figure 2). Interestingly some of the bacterial isolates (e.g. K-8, K-9, K-10, K-11) exhibited very strong protease activity compared to others (e.g. K4, K12). Qualitative and quantitative analysis of these enzymes are in progress in our laboratory. Results obtained from this analysis will determine the potential application of our soil isolate(s) in industrial and academic benefit.

Table 1.Morphological study on TSA plate and gram staining.

\begin{tabular}{|c|c|c|c|}
\hline $\begin{array}{l}\text { Number of soil bacterial } \\
\text { isolate }\end{array}$ & Color of colony & Description of colony & Gram staining \\
\hline K1 & Greenish & Irregular, large, transparent & + \\
\hline K2 & Greenish & Irregular, large, transparent & + \\
\hline K3 & Greenish & Irregular, large, transparent & + \\
\hline K4 & Greenish & Irregular, large, transparent & + \\
\hline K5 & Copper-copper & Round shaped, small, transparent & + \\
\hline K6 & Copper-copper & Round shaped, small, transparent & + \\
\hline K7 & Greenish & Irregular, transparent, large & + \\
\hline K8 & Greenish & Irregular, large, transparent & + \\
\hline K9 & Greenish & Irregular, large, transparent & - \\
\hline K10 & Greenish & Irregular, large, transparent & - \\
\hline K11 & Greenish & Irregular, large, transparent & + \\
\hline K12 & Greenish & Irregular, large, transparent & - \\
\hline K13 & Greenish & Irregular, large, transparent & - \\
\hline K14 & Greenish & Irregular, large, transparent & + \\
\hline K15 & White (opaque) & Round shaped, small, transparent & + \\
\hline K16 & White (opaque) & Round shaped, small, transparent & + \\
\hline K17 & Yellowish & Round shaped, small, transparent & + \\
\hline K18 & Greenish & Irregular, large, transparent & + \\
\hline K19 & Greenish & Irregular, large, transparent & - \\
\hline S. aureus (positive control) & N/A & N/A & + \\
\hline E. coli (negative control) & N/A & N/A & - \\
\hline
\end{tabular}


Table 2. Biochemical analysis of bacterial isolates from soil samples.

\begin{tabular}{|c|c|c|c|c|c|c|}
\hline \multirow[t]{2}{*}{ Isolate No } & \multicolumn{6}{|c|}{ Biochemical test } \\
\hline & Oxidase & Catalase & Coagulase & S. Citrate & KIA (Butt/Slant) & Protease \\
\hline k1 & + & + & - & + & acid/acid & + \\
\hline K2 & + & + & - & + & alkaline/alkaline & + \\
\hline K3 & + & + & - & + & acid/acid & + \\
\hline K4 & + & + & - & + & acid/alkaline $\left(\mathrm{H}_{2} \mathrm{~S}\right)$ & + \\
\hline K5 & + & + & - & + & acid/acid & + \\
\hline K6 & + & + & - & + & alkaline/alkaline $\left(\mathrm{H}_{2} \mathrm{~S}\right)$ & + \\
\hline K7 & + & + & - & + & acid/acid & + \\
\hline K8 & + & + & - & + & acid/acid & + \\
\hline K9 & + & + & + & + & alkaline/alkaline & + \\
\hline K10 & + & + & + & + & alkaline/alkaline & + \\
\hline K11 & + & + & + & + & alkaline/alkaline & + \\
\hline K12 & + & + & + & + & alkaline/alkaline & + \\
\hline K13 & + & + & + & + & alkaline/alkaline & + \\
\hline K14 & + & + & + & + & alkaline/alkaline & + \\
\hline K15 & + & + & + & + & acid/acid & + \\
\hline K16 & + & + & + & + & acid/alkaline & + \\
\hline K17 & + & + & + & + & acid/alkaline & + \\
\hline K18 & + & + & + & + & acid/alkaline & + \\
\hline K19 & + & + & + & + & acid(gas)/alkaline & + \\
\hline E. coli ATCC25923 & - & + & - & - & acid/acid & - \\
\hline S. aureus ATCC25922 & - & + & + & + & acid/acid & N/A \\
\hline Pseudomonas aeruginosa & + & + & - & + & N/A & + \\
\hline
\end{tabular}

+ = positive result, - = negative result, $\mathrm{Y}=$ yellow (acid), $\mathrm{P}=$ pink (alkaline), Black $=\mathrm{H}_{2} \mathrm{~S}, \mathrm{~N} / \mathrm{A}=$ not applicable.

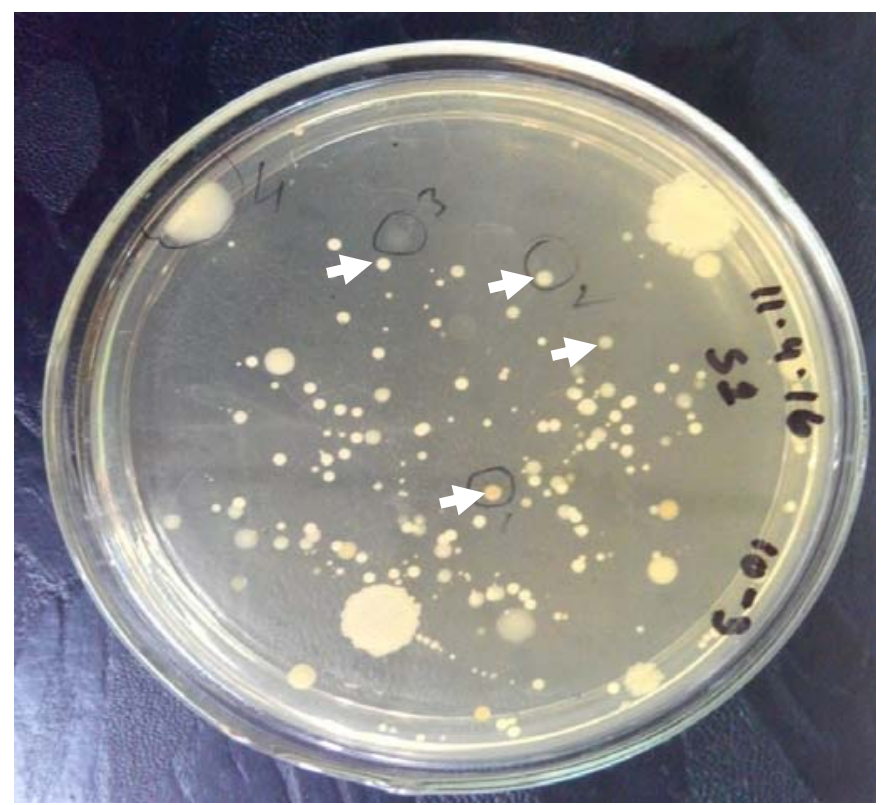

Figure 1 . Single colony of soil bacteria isolated in TSA plate. 


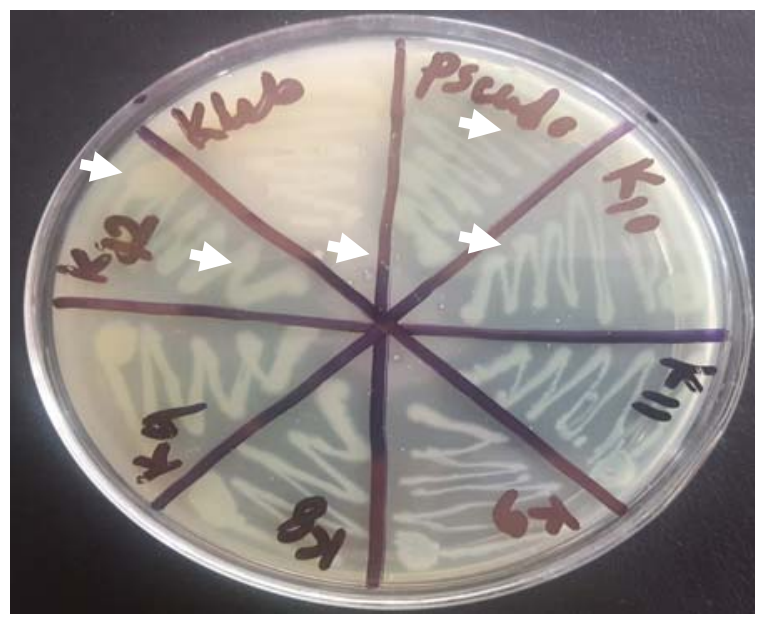

Figure 2. Protease producing bacteria isolated from soil samples.

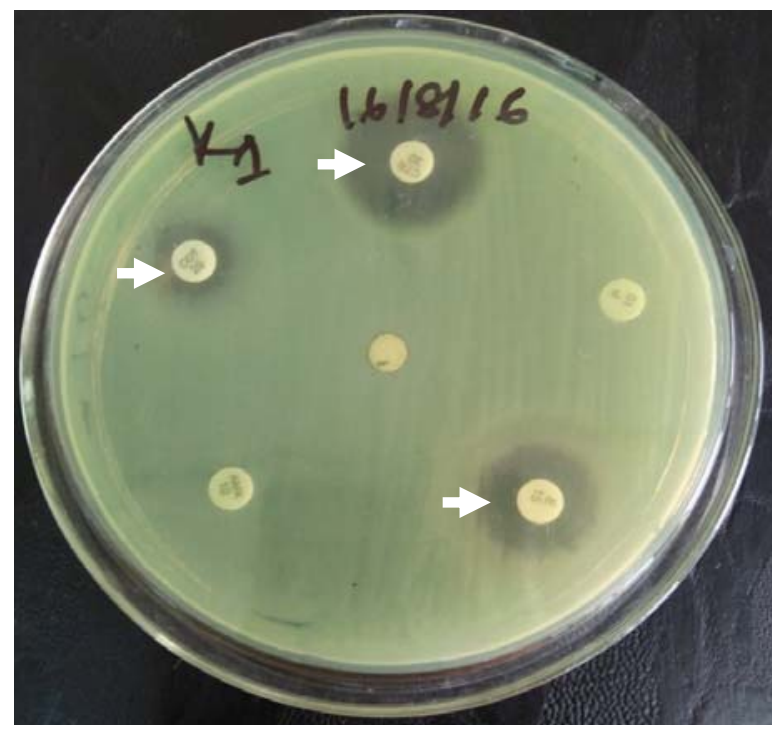

Figure 3. Zone of inhibition of antibiotic sensitivity test.

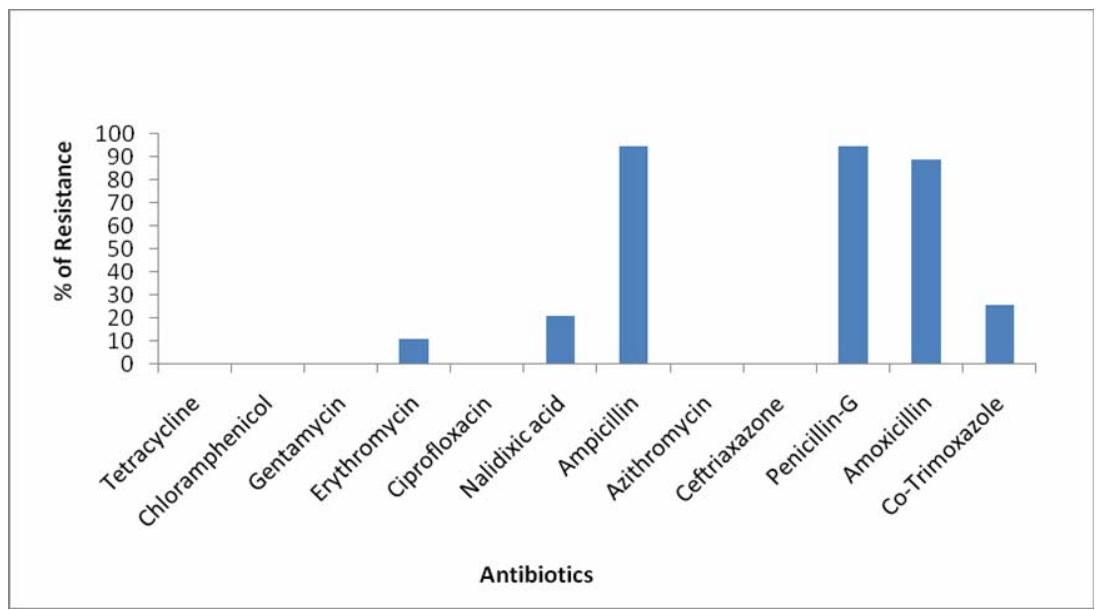

Figure 4. Percent of antibiotic resistance against isolated soil bacteria. 
Antibiotic discovered from bacteria is one of the most important secondary metabolites. More than $80 \%$ of antibiotics are in clinical use originated from bacteria isolated from soil. ${ }^{25}$ Many soil bacteria are naturally resistant to antibiotics such as $\beta$-lactams. In this study, bacterial isolates from soil were studied for the development of resistance to some antibiotics that are being in clinical use. Soil bacterial isolates were studied for their sensitivity toward commonly used antibiotics. It was found that all bacterial isolates were sensitive to tetracycline, chloramphenicol, gentamycin, ciprofloxacin, azithromycin and ceftriaxone. About $95 \%$ of the bacterial isolates were resistant to penicillin-G and ampicillin. About 89, 26, 21 and $11 \%$ of the bacterial isolates were resistant to amoxicillin, co-trimoxazole, nalidixic acid and erythromycin, respectively (Figure 4). Further studies are required to understand the molecular basis of the development of antibiotic resistance of these strains. In recent years new bacterial pathogens are being found to be emerging with resistance to almost all antibiotics. It has become critical to develop novel antibiotics to overcome forth coming challenge of treating infectious diseases. ${ }^{26,27}$ We were interested if any of the soil bacterial isolates has the ability to produce chemicals that inhibit other bacterial growth. All the isolates were tested for antibacterial activity against both gram positive and gram negative bacteria (data not shown). Bacterial isolates from soil showed bactericidal activity against pathogenic bacteria. These results indicate isolates produce bactericidal/inhibitory factors for other bacteria. Further studies are in progress to isolate and characterize antibacterial principle produced by our bacterial isolates from soil.

\section{CONCLUSION}

In this study, soil bacteria from Dhaka city were found to be both gram positive and gram negative. Bacterial isolates were found to produce secondary metabolites of antibacterial principles and enzymes of commercial importance. This preliminary study may lead to discovery of antibiotics and other bioactive compounds.

\section{ACKNOWLEDGEMENTS}

The authors wish to thank the Department of Pharmacy, ASA University Bangladesh for providing the necessary facilities for carrying out the study.

\section{REFERENCES}

1. Braga, R.M., Dourado, M.N.and Araújo, W.L. 2016. Microbial interactions: ecology in a molecular perspective. Braz J. Microbiol. 47, 86-98.

2. Hongmei, J., Aitchison, J., Lacap, D., Peerapornpisal, Y., Sompong, U. and Pointing, S. 2005. Community phylogenetic analysis of moderately thermophilic cyanobacterial mats from China, the Philippines and Thailand. Extremophiles. 9, 325-332.

3. Eilers, K.G., Debenport, S., Anderson, S. and Fierer, N. 2012. Digging deeper to find unique microbial communities: The strong effect of depth on the structure of bacterial and archaeal communities in soil. Soil Biol. and Biochem. 50, 5865.

4. Angelov, G.B. 2008. Heavy metal pollution in the Boatin Reserve (Bulgaria). Turkish J. Botany. 32, 155-160.

5. Brock, T. D. and Madigan, M. T. 1991. Biology of microorganisms. $6^{\text {th }}$ edn. Prentice-Hall International Inc., USA.

6. Makhalanyane, T. P., Valverde, A., Gunnigle, E., Frossard, A., Ramond, J., and Cowan, D. A. 2015. Microbial ecology of hot desert edaphic systems. FEMS Micrology Rev. 39, 203-221.

7. Smith, J.E.1989. Perspective in biotechnology and applied microbiology. Murray Moo Young. 105-134.

8. Bulock, J. 1987. Basic Biotechnology. Academic press. 425448.

9. Vandemme, E.J. 1948. Biotechnology of Industrial Antibiotics. Dekker Series, Marcel Dekker Inc., New York. 35, 22:3-42.

10. Saha, A. and Santra, S.C. 2014. Isolation and characterization of bacteria isolated from municipal solid waste for production of industrial enzymes and waste degradation. J. Microbiol. Exp 1, 00003.

11. Goldstein, D.A., Tinland, B. and Gilbertson, L.A. 2005. Human safety and genetically modified plants: A review of antibiotic resistance markers and future transformation selection technologies. J. Appl. Microbiol. 99, 7-23. 
12. Badosa, E., Moreno, C. and Montesinos, E.2004. Lack of detection of ampicillin resistance gene transfer from Bt176 transgenic corn to culturable bacteria under field conditions. FEMS Microbiol. Ecol. 48, 169-78.

13. Ball, A.P., Bartlett, J.G., Craig, W.A., Drusano, G.L., Felmingham, D., Garau, J.A., Klugman, K.P., Low, D.E., Mandell, L.A., Rubinstein, E. and Tillotson, G.S. 2004. Future trends in antimicrobial chemotherapy: expert opinion on the 43rd ICAAC. J. Chemother. 16, 419-436.

14. Hancock, R.E.W. 2007.The end of an era. Nat. Rev. Drug. Discov. 6, 28.

15. Stachelhaus, T., Schneider, A. and Marahiel, M.A. 1995. Rational design of peptide antibiotics by targeted replacement of bacterial and fungal domains. Sci. 269, 6972.

16. Drablos, F., Nicholson, D.G. and Ronning, M.E. 1999. Study of zinc coordination in bacitracin A. Biochim. Biophys. Acta.1431, 433-442.

17. Brakstad, O.G., Throne-Holst, M., Netzer, R., Stoeckel, D.M. and Atlas, R.M. 2015. Microbial communities related to biodegradation of dispersed macondo oil at low seawater temperature with Norwegian coastal seawater. Microb Biotechnol. 18, 989-98.

18. Nurullah, Akcan and Fikret, Uyar. 2011. Production of extracellular alkaline protease from Bacillus subtilis RSKK96 with solid state fermentation. Eu Asian J. of Biosciences. 5, 64-72.

19. Louis, B.P., Maron, P.A., Viaud, V., Leterme, P. and Menasseri-Aubry, S. 2016. Soil C and N models that integrate microbial diversity. Environ Chem Lett. 14,331344.
20. Begum, K, Mannan, J.S., Rahman,M.M., Mitchel-Antoine A, Opoku R, et al. (2017) Identification of antibiotic producing bacteria from soil samples of Dhaka, Bangladesh. J. Microbiol. Exp. 4, 00134

21. Biemer, J.J. 1973. Antimicrobial susceptibility testing by the kirby-bauer disc diffusion method. Ann Clin Lab Sci. 3, 13540.

22. Barlaz, M.A.,Schaefer,D.M. and HamR.K. 1989. Bacterial population development and chemical characteristics of refuse decomposition in a simulated sanitary landfill. Appl Environ. Microbiol. 55, 55-65.

23. Song, L., Wang. Y., Zhao. H. and Long, D.T. 2015. Composition of bacterial and archaeal communities during landfill refuse decomposition processes. Microbiol. Res. 181, 105-11.

24. Alexander, M. 1961. Introduction to soil microbiology. (2nd edn), John Wiley and Sons Inc, New York, USA.

25. Martín, M.F. and Liras, P. 1989.Organization and expression of genes involved in the biosynthesis of antibiotics and other secondary metabolites. Ann. Rev. Microbiol. 43, 173-206.

26. Kealey, C., Creaven, C.A., Murphy, C.D. and Brady, C.B. 2017. New approaches to antibiotic discovery. Biotechnol. Lett. (In Press).

27. Marston, H.D, Dixon, D.M., Knisely, J.M., Palmore, T.N. and Fauci, A.S. 2016. Antimicrobial resistance. JAMA 316, 1193-1204. 